\title{
Amino Acids and Peptides as Versatile Ligands in the Synthesis of Antiproliferative Gold Complexes ${ }^{\dagger}$
}

\author{
Tina P. Andrejević ${ }^{1}$, Biljana Đ. Glišić ${ }^{1, *(1)}$ and Miloš I. Djuran ${ }^{2, *}$ \\ 1 Faculty of Science, Department of Chemistry, University of Kragujevac, R. Domanovića 12, \\ 34000 Kragujevac, Serbia; tina.andrejevic@pmf.kg.ac.rs \\ 2 Serbian Academy of Sciences and Arts, Knez Mihailova 35, 11000 Belgrade, Serbia \\ * Correspondence: biljana.glisic@pmf.kg.ac.rs (B.Đ.G.); milos.djuran@pmf.kg.ac.rs (M.I.D.); \\ Tel.: +381-34-336-223 (B.Đ.G.); +381-34-300-251 (M.I.D.); Fax: +381-34-335-040 (B.Đ.G. \& M.I.D.) \\ + In Honor of Professor Bernd Giese on the Occasion of His 80th Birthday.
}

Received: 6 March 2020; Accepted: 24 March 2020; Published: 27 March 2020

\begin{abstract}
Gold complexes have been traditionally employed in medicine, and currently, some gold(I) complexes, such as auranofin, are clinically used in the treatment of rheumatoid arthritis. In the last decades, both gold(I) and gold(III) complexes with different types of ligands have gained considerable attention as potential antitumor agents, showing superior activity both in vitro and in vivo to some of the clinically used agents. The present review article summarizes the results achieved in the field of synthesis and evaluation of gold complexes with amino acids and peptides moieties for their cytotoxicity. The first section provides an overview of the gold(I) complexes with amino acids and peptides, which have shown antiproliferative activity, while the second part is focused on the activity of gold(III) complexes with these ligands. A systematic summary of the results achieved in the field of gold(I/III) complexes with amino acids and peptides could contribute to the future development of metal complexes with these biocompatible ligands as promising antitumor agents.
\end{abstract}

Keywords: gold complexes; amino acids; peptides; cytotoxicity

\section{Introduction}

Gold and its compounds have been used for the treatment of a wide range of diseases throughout the history of civilization [1]. The use of gold in modern medicine began with the discovery of the in vitro bacteriostatic properties of the gold(I) complex, $\mathrm{K}\left[\mathrm{Au}(\mathrm{CN})_{2}\right]$, by the German bacteriologist Robert Koch [2]. This gold(I) complex was found to be lethal to the microorganism, Mycobacterium tuberculosis, which is causative agent of tuberculosis [2]. After its initial use for tuberculosis with favorable results, serious toxic side-effects were observed for $\mathrm{K}\left[\mathrm{Au}(\mathrm{CN})_{2}\right]$ complex and the treatment was switched to the less toxic gold(I) thiolate complexes (AuSR). The mistaken belief that the Mycobacterium tuberculosis was also a causative agent of rheumatoid arthritis led Landé and Forestier to use gold(I) thiolate complexes for the treatment of this disease [3]. After thirty years of medicinal debate, in 1960, British Empire Rheumatism Council finally confirmed the beneficial effects of the gold(I) thiolate complexes against rheumatoid arthritis [3]. Since that time, these complexes have been widely used in the treatment of a variety of rheumatic diseases including psoriatic arthritis, juvenile arthritis, palindromic rheumatism and discoid lupus erythematosus [3]. Nowadays, chrysotherapy is an accepted part the modern medicine and refers to the use of gold-based formulations for the treatment of joint pain and inflammatory diseases [4].

Following the medicinal relevance of gold complexes for the treatment of rheumatoid arthritis, research has continued to uncover the potential of gold complexes as agents for the treatment of cancer [4-13], and various bacterial and fungal infections and tropical diseases, such as malaria, 
trypanosomiasis and leishmaniasis [14,15]. In some cases, gold complexes were found to be more active than the clinically used agents, e.g., cisplatin for the cancer treatment [5]. Some gold complexes showed an outstanding in vitro cytotoxicity toward cisplatin-resistant tumor cell lines, which indicates the difference in the mode of action between them and platinum-based agents [5]. Indeed, it was found that the antitumor activity of cisplatin is based on its interaction with DNA, while the antiproliferative activity of gold complexes usually involves the inhibition of enzymes, especially those containing thiol groups, such as thioredoxin reductase (TrxR) [6].

Different classes of ligands have been used for the synthesis of biologically active gold complexes, including phosphines, $N$-heterocyclic carbenes, thiolates, polyamines, pyridine, bipyridine, terpyridine, phenanthroline, and their derivatives, macrocyclic ligands (cyclam), porphyrins and dithiocarbamates [4-15]. Besides them, amino acids and peptides represent two important classes of ligands which are also important as building blocks of proteins and enzymes and show a wide range of biological activities [16]. As constituents of proteins, amino acids and peptides can be considered as biocompatible ligands that can deliver $\mathrm{Au}(\mathrm{I})$ ion to its biological target or, as polydentate ligands, they can stabilize the $\mathrm{Au}(\mathrm{III})$ ion, preventing its reduction to $\mathrm{Au}(\mathrm{I})$ or/and $\mathrm{Au}(0)$ under physiological conditions. More importantly, metal complexes with this type of ligand can be more selective toward the abnormal cells in respect to the healthy ones, due to the fact that the abnormal cells overexpress amino acids receptors and need more nutrients [17].

The aim of this review is to present the findings obtained in the field of synthesis and evaluation of gold(I) and gold(III) complexes containing amino acids and peptides moieties for their antiproliferative potential.

\section{Gold(I) Complexes Containing Amino Acids and Peptides Moieties}

Considering the great importance of ferrocenyl group in drug design [18], two ferrocene bioconjugates, FcCO-TrpOMe and $\mathrm{FcCO}-\mathrm{ProNH}_{2}(\mathrm{Fc}=$ ferrocenyl, TrpOMe $=$ methyl ester of tryptophan and $\mathrm{ProNH}_{2}=$ prolinamide) were reacted with an equimolar amount of $\left[\mathrm{Au}(\mathrm{acac})\left(\mathrm{PR}_{3}\right)\right]$ (acac = acetylacetonate, $\mathrm{PR}_{3}=\mathrm{PPh}_{3}$, triphenylphosphine or $\mathrm{PPh}_{2} \mathrm{Py}$, 2-pyridyldiphenylphosphine) to yield gold(I) complexes, [Au(FcCO-TrpOMe-N)(PR $)]\left(\mathrm{PPh}_{3}\right.$ (1) and $\mathrm{PPh}_{2} \mathrm{Py}$ (2)) and [Au(FcCO-ProNH $\left.\left.{ }_{2}-\mathrm{N}\right)\left(\mathrm{PR}_{3}\right)\right]\left(\mathrm{PPh}_{3}\right.$ (3) and $\mathrm{PPh}_{2} \mathrm{Py}$ (4)) (Figure 1) [19]. Similarly, the reaction of FcCO-MetOMe with $\left[\mathrm{Au}\left(\mathrm{CF}_{3} \mathrm{SO}_{3}\right)\left(\mathrm{PR}_{3}\right)\right]$ (MetOMe = methyl ester of methionine) led to the formation of [ $\left.\mathrm{Au}(\mathrm{FcCO}-\mathrm{MetOMe}-\mathrm{S})\left(\mathrm{PR}_{3}\right)\right] \mathrm{CF}_{3} \mathrm{SO}_{3}\left(\mathrm{PPh}_{3}\right.$ (5) and $\left.\mathrm{PPh}_{2} \mathrm{Py}(6)\right)$ complexes (Figure 1) [19]. The cytotoxicity of ferrocene bioconjugates and corresponding gold(I) complexes 1-6 was evaluated by MTT assay against two human tumor cell lines, HeLa (cervical cancer) and MCF-7 (breast cancer), and one murine cell line, N1E-115 (derived from mouse neuroblastoma C-1300) (Table 1). The evaluated gold(I) complexes 1-6 appeared to be cytotoxic against these three tumor cell lines, while the corresponding ferrocene bioconjugates used as ligands, $\mathrm{FcCO}-\mathrm{TrpOMe}, \mathrm{FcCO}-\mathrm{ProNH}_{2}$ and FCCO-MetOMe, did not show antiproliferative activity $\left(\mathrm{IC}_{50}>1000 \mu \mathrm{M}\right.$, the $\mathrm{IC}_{50}$ value is defined as concentration required to inhibit tumor cell proliferation by $50 \%$ compared to the control cells). The $\mathrm{IC}_{50}$ values of the gold(I) complexes determined after $48 \mathrm{~h}$ are in range from 18 to $32 \mu \mathrm{M}$ in HeLa cells, 15 to $52 \mu \mathrm{M}$ in MCF-7 cells and $<10$ to $54 \mu \mathrm{M}$ in N1E-115 cells (Table 1). Among the complexes, gold(I) complex 5 with MetOMe and $\mathrm{PPh}_{3}$ in its structure was shown as the most effective against the HeLa cell line; while 4, having $\mathrm{ProNH}_{2}$ and $\mathrm{PPh}_{2} \mathrm{Py}$ moieties, displayed the best activity in the murine cell line, although all gold(I) complexes were less cytotoxic than the reference drug doxorubicin, with $\mathrm{IC}_{50}$ values of approximately $1.5 \mu \mathrm{M}$ [19]. For all compounds, the percentage of cell survival decreased with the increasing of exposure time, although the difference between 24 and $48 \mathrm{~h}$ was not found to be significant. Complex 4 induced the cell death through apoptosis and formation of reactive oxygen species (ROS) in tumor cells, while the gold(I) complexes did not act as DNA intercalators. 


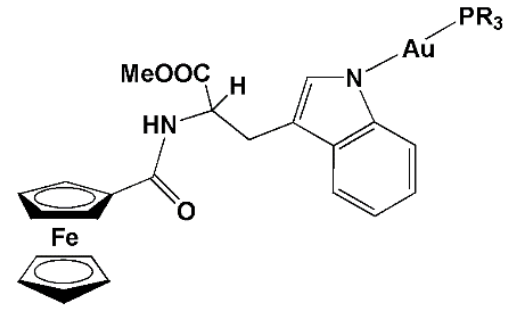

[Au(FcCO-TrpOMe-N)(PPh 3$)]$ (1) [Au(FcCO-TrpOMe-N)(PPh $\left.\left.{ }_{2} \mathrm{Py}\right)\right](\mathbf{2})$

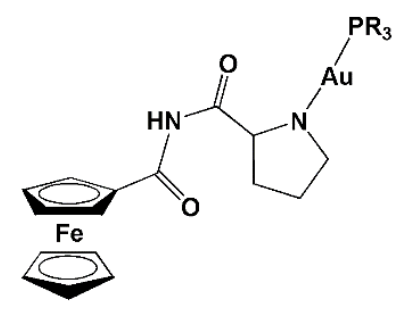

[Au(FcCO-ProNH $\left.\left.\mathrm{F}_{2}-\mathrm{N}\right)\left(\mathrm{PPh}_{3}\right)\right]$ (3) $\left[\mathrm{Au}\left(\mathrm{FcCO}-\mathrm{ProNH}_{2}-\mathrm{N}\right)\left(\mathrm{PPh}_{2} \mathrm{Py}\right)\right](4)$

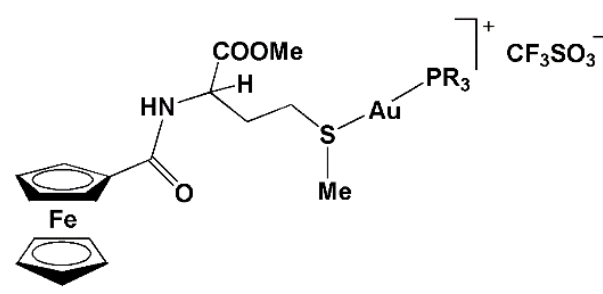

[Au(FcCO-MetOMe-S)( $\left.\left.\mathrm{PPh}_{3}\right)\right] \mathrm{CF}_{3} \mathrm{SO}_{3}(\mathbf{5})$ [Au(FcCO-MetOMe-S)( $\left.\left.\mathrm{PPh}_{2} \mathrm{Py}\right)\right] \mathrm{CF}_{3} \mathrm{SO}_{3}(6)$

Figure 1. Gold(I) complexes with the ferrocene bioconjugates 1-6 showing cytotoxic activity [19].

Table 1. In vitro cytotoxic activity $\left(\mathrm{IC}_{50}, 48 \mathrm{~h}, \mu \mathrm{M}\right)$ of gold(I) complexes with the ferrocene bioconjugates 1-6 [19].

\begin{tabular}{cccc}
\hline \multicolumn{1}{c}{ Cell Line $^{\text {a }}$} & HeLa & MCF-7 & N1E-115 \\
\hline $\mathbf{1}$ & $32 \pm 1.8$ & $15 \pm 1.2$ & $27 \pm 2.2$ \\
$\mathbf{2}$ & $22 \pm 1.9$ & $45 \pm 1.7$ & $26 \pm 1.6$ \\
$\mathbf{3}$ & $28 \pm 1.6$ & $52 \pm 1.2$ & $54 \pm 2.3$ \\
$\mathbf{4}$ & $29 \pm 1.3$ & $32 \pm 2.5$ & $<10 \pm 2.2$ \\
$\mathbf{5}$ & $18 \pm 1.4$ & $15 \pm 1.8$ & $29 \pm 1.7$ \\
\hline cervical cancer, MCF-7 = breast cancer and N1E-115 = mouse neuroblastoma C-1300.
\end{tabular}

The antiproliferative activity against different tumor cell lines was shown by gold(I) complexes obtained from the reaction of $\left[\mathrm{Au}(\mathrm{SPyCOOH})\left(\mathrm{PR}_{3}\right)\right]$ complex $(\mathrm{SPyCOOH}=$ nicotinic acid thiolate) by the functionalization of its carboxylic group with different amino acids, ester or amide derivatives of these amino acids or with peptide moieties [20,21]. Gold(I) complexes 7-24 of the general formula [Au(SPyCOR) $\left.\left(\mathrm{PPh}_{3}\right)\right]$, in which $\mathrm{R}=$ methyl ester of amino acid (7-12), amino acid (13-18) and amide derivative of the corresponding amino acid (19-24) have been structurally modified. This modification was performed by changing the type of phosphine ligand in [Au(SPyCOR) $\left.\left(\mathrm{PPh}_{3}\right)\right]$ complex $\left(\mathrm{PPh}_{2} \mathrm{Py}\right.$ instead of $\mathrm{PPh}_{3} ;$ complex 25) and the nature of the coupled amino acid (R) including its structural modification or peptide functionalization (26-32) and increasing the number of $\mathrm{Au}(\mathrm{I})$ ions per complex unit (33) (Figure 2a,b) [21]. The antiproliferative activity of these gold(I) complexes was evaluated against three different human tumor cell lines, A549 (lung carcinoma), Jurkat (T-cell leukemia) and MiaPaca2 (pancreatic carcinoma), as well as against non-tumor R69 (lymphoid cell line) and 293T (embryonic kidney fibroblasts), and these cells were exposed to different concentrations of each complex for $24 \mathrm{~h}$ (Table 2). As can be seen from this table, the complexes 7-24 were active against the investigated tumor cell lines at low micromolar range, with Jurkat cells being the most sensitive; their $\mathrm{IC}_{50}$ values fall in the range from 7.4 to $30.5 \mu \mathrm{M}$ in A549, 8.2 to $27.2 \mu \mathrm{M}$ in MiaPaca2 and 2.4 to $7.7 \mu \mathrm{M}$ in Jurkat cells. Moreover, these complexes exhibited some selectivity for leukemia cells in respect to the non-tumor R69 cells, but this difference was not observed in the case of solid tumors. The cytotoxic activity of the ester complexes 7-12 was slightly higher than that of the corresponding precursor, $\left[\mathrm{Au}(\mathrm{SPyCOOH})\left(\mathrm{PPh}_{3}\right)\right]$, in all the tested tumor cell lines, with the exception of MiaPaca2 (Table 2). The complexes containing coupled amino acids 13-18 and amide derivatives of these amino acids 19-24 were, in general, less active than the ester analogues $\mathbf{7 - 1 2}$, although the difference in the activity is not remarkable. The proline-containing complex $\mathbf{1 2}$ was found to induce changes in cell and nucleus morphology, loss of the mitochondrial membrane potential, production of ROS and to inhibit the thioredoxin reductase ( $\mathrm{Tr} X)$, an enzyme which acts as a target for biologically active gold(I/III) complexes [21]. Interestingly, gold(I) species 7-24 showed much higher antiproliferative activities in vitro in the used cell lines than the cisplatin, the well-known antitumor agent used in medicine for the treatment of various cancers (Table 2) [22]. 
a)

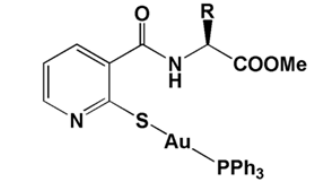

[Au(SPyCO-GlyOMe-S) $\left.\left(\mathrm{PPh}_{3}\right)\right] \quad$ (7) [Au(SPyCO-AlaOMe-S)( $\left.\left(\mathrm{PPh}_{3}\right)\right]$ (8) [Au(SPyCO-ValOMe-S) $\left.\left(\mathrm{PPh}_{3}\right)\right]$ (9) [Au(SPyCO-PheOMe-S)(PPh $)]$ (10) [Au(SPyCO-MetOMe-S) $\left.\left(\mathrm{PPh}_{3}\right)\right]$ (11) [Au(SPyCO-ProOMe-S) $\left.\left(\mathrm{PPh}_{3}\right)\right]$ (12)

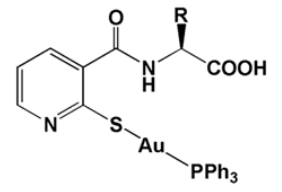

[Au(SPyCO-GlyOH-S)(PPh $)]$ (13) [Au(SPyCO-AlaOH-S) $\left.\left(\mathrm{PPh}_{3}\right)\right]$ (14) [Au(SPyCO-ValOH-S) $\left.\left(\mathrm{PPh}_{3}\right)\right]$ (15) $\left[\mathrm{Au}(\mathrm{SPyCO}-\mathrm{PheOH}-\mathrm{S})\left(\mathrm{PPh}_{3}\right)\right]$ (16) [Au(SPyCO-MetOH-S)(PPh ] (17) [Au(SPyCO-ProOH-S)( $\left.\left(\mathrm{PPh}_{3}\right)\right]$ (18)

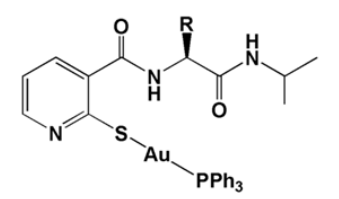

[Au(SPyCO-GlyNH'Pr-S)( $\left.\left(\mathrm{PPh}_{3}\right)\right]$ (19) [Au(SPyCO-AlaNH'i Pr-S) $\left.\left(\mathrm{PPh}_{3}\right)\right]$ (20) [Au(SPyCO-ValNH'Pr-S) $\left.\left(\mathrm{PPh}_{3}\right)\right]$ (21) [Au(SPyCO-PheNH'i- $\left.\mathrm{Pr}-\mathrm{S})\left(\mathrm{PPh}_{3}\right)\right]$ (22) [Au(SPyCO-MetNHi'Pr-S)(PPh $\left.\left.{ }_{3}\right)\right]$ (23) [Au(SPyCO-ProNHi'Pr-S) $\left(\mathrm{PPh}_{3}\right)$ ] (24)

b)

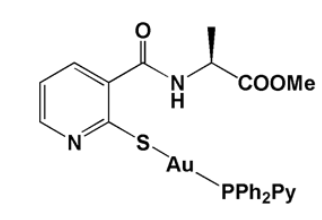

[Au(SPyCO-AlaOMe-S)(PPh $2 \mathrm{Py})](25)$<smiles>CC(=O)C(CCCCNC(=O)OC(C)(C)C)NC(=O)c1cccnc1SCc1ccccc1</smiles>

[Au(SPyCO-Boc-LysOMe-S)(PPh $)$ ] (26)<smiles>CC(=O)C(CCCN)NC(=O)c1cccnc1SCc1ccccc1</smiles>

[Au(SPyCO-HLysOMe-S)(PPh 3 ]) (27)<smiles>CC(=O)[C@H]1CCCN1C(=O)CNC(=O)c1cccnc1S[GaH]c1ccccc1</smiles>

[Au(SPyCO-Gly-ProOMe-S) $\left.\left(\mathrm{PPh}_{3}\right)\right]$ (28)

$\left[\mathrm{Au}\left(\mathrm{SPyCO}_{\mathrm{AlaNEt}}-\mathrm{S}\right)\left(\mathrm{PPh}_{3}\right)\right](\mathbf{2 9})$<smiles>CC(=O)[C@H](C)NC(=O)c1cccnc1S[As]c1ccccc1</smiles>

[Au(SPyCO-AlaOMe-S) $\left.\left(\mathrm{PPh}_{3}\right)\right]$ (30)<smiles>CC(=O)[C@H](Cc1ccccc1)NC(=O)c1cccnc1SCc1ccccc1</smiles>

[Au(SPyCO-PheOMe-S) $\left.\left(\mathrm{PPh}_{3}\right)\right]($ 31)<smiles>C[C@H](NC(=O)c1cccnc1S[14C](=O)c1ccccc1)C(=O)O</smiles>

$\left[\mathrm{Au}(\mathrm{SPyCO}-\mathrm{AlaOH}-\mathrm{S})\left(\mathrm{PPh}_{3}\right)\right]($ 32)

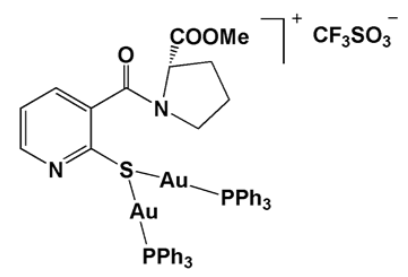

$\left[\mathrm{Au}_{2}(\mathrm{SPyCO}-\mathrm{ProOMe}-\mathrm{S})\left(\mathrm{PPh}_{3}\right)_{2}\right] \mathrm{CF}_{3} \mathrm{SO}_{3}(\mathbf{3 3})$

Figure 2. (a) Gold(I) complexes 7-24 of the general formula [ $\left.\mathrm{Au}(\mathrm{SPyCOR})\left(\mathrm{PPh}_{3}\right)\right]$ in which nicotinic acid thiolate is coupled with methyl ester of amino acid (7-12), amino acid (13-18) and amide derivative of the corresponding amino acid (19-24), and (b) complexes 25-33 obtained by different structural modifications of $\left[\mathrm{Au}(\mathrm{SPyCOR})\left(\mathrm{PPh}_{3}\right)\right]$ complex showing cytotoxic activity $[20,21]$.

The $\mathrm{IC}_{50}$ values of the structurally modified complexes 25-33 (Figure $2 \mathrm{~b}$ ) are also at low micromolar concentrations (4.1-33.5 $\mu \mathrm{M}$ in A549, 1.2-29.3 $\mu \mathrm{M}$ in MiaPaca2 and 0.9-36.5 $\mu \mathrm{M}$ in Jurkat cells), with the Jurkat cell line being, in most cases, more sensitive to these complexes than A549 and MiaPaca2 (Table 2). However, for the latter two cell lines, the complexes 25-33 are more active than cisplatin $\left(\mathrm{IC}_{50}=105\right.$ and $71 \mu \mathrm{M}$ in A549 and MiaPaca2, respectively), while, in the case of Jurkat cell line, the $\mathrm{IC}_{50}$ values for the gold(I) complexes and cisplatin are similar $\left(\mathrm{IC}_{50}=7.4 \mu \mathrm{M}\right)$. The change of the type of phosphine ligand coordinated to the $\mathrm{Au}(\mathrm{I})$ ion $\left(\mathrm{PPh}_{2} \mathrm{Py}\right.$ instead of $\mathrm{PPh}_{3}$; complex 25) resulted in the same or slightly greater cytotoxicity in Jurkat and R69 cell lines, respectively, while in the remaining cell lines, lower cytotoxicity was observed in respect to the analogue complex 7, although the differences are not significant. The coupling of lysine ester afforded complex $\mathbf{2 6}$ having the good antiproliferative activity, while the removal of the protective Boc (Boc is tert-butoxycarbonyl) group in this complex significantly decreased the cytotoxicity of the complex 27. This was ascribed to the presence of free amino group, which acts as a strong nucleophile and can react with the other biomolecules, preventing the Au(I) ion 
to reach the target [21]. The gold(I) complexes having Gly-ProOMe dipeptide (28), tertiary amide (29), D-amino esters (30 and 31) and D-amino acids (32) in their structures have shown lower cytotoxicity than the corresponding analogues (Table 2). Among the investigated complexes, the best antiproliferative activity was demonstrated by the dinuclear gold(I) complex 33, which is functionalized as ester and contains rigid proline as amino acid moiety (Figure $2 \mathrm{~b}$ ). The $\mathrm{IC}_{50}$ values of this complex are found to be in the low micromolar range and even in the submicromolar range in the Jurkat cell line and are also lower than those for cisplatin (Table 2).

Table 2. In vitro cytotoxic activity $\left(\mathrm{IC}_{50}, 24 \mathrm{~h}, \mu \mathrm{M}\right)$ of thiolate-gold(I) complexes of the general formula $\left[\mathrm{Au}(\mathrm{SPyCOR})\left(\mathrm{PPh}_{3}\right)\right]$ in which nicotinic acid thiolate is coupled with methyl ester of amino acid (7-12), amino acid (13-18) and amide derivative of the corresponding amino acid (19-24) and complexes obtained by different structural modifications of [Au(SPyCOR) $\left.\left(\mathrm{PPh}_{3}\right)\right]$ complex (25-33) [21].

\begin{tabular}{|c|c|c|c|c|c|}
\hline Cell Line ${ }^{a}$ & A549 & MiaPaca2 & Jurkat & $293 \mathrm{~T}$ & R69 \\
\hline$\left[\mathrm{Au}(\mathrm{SPyCOOH})\left(\mathrm{PPh}_{3}\right)\right]$ & $15.5 \pm 0.92$ & $9.2 \pm 0.28$ & $4.6 \pm 0.08$ & $4.6 \pm 0.13$ & $16 \pm 0.64$ \\
\hline \multicolumn{6}{|c|}{$\left[\mathrm{Au}(\mathrm{SPyCOOH})\left(\mathrm{PR}_{3}\right)\right], \mathrm{R}=$ methyl ester of amino acid } \\
\hline 7 & $11.5 \pm 0.55$ & $9.7 \pm 0.22$ & $3.8 \pm 0.07$ & $4.2 \pm 0.08$ & $8.6 \pm 0.33$ \\
\hline 8 & $13.7 \pm 0.71$ & $11.0 \pm 0.20$ & $4.0 \pm 0.07$ & $2.7 \pm 0.07$ & $2.2 \pm 0.08$ \\
\hline 9 & $10.9 \pm 0.40$ & $10.2 \pm 0.25$ & $3.3 \pm 0.05$ & $10.7 \pm 0.31$ & $19.0 \pm 0.60$ \\
\hline 10 & $8.9 \pm 0.36$ & $12.3 \pm 0.37$ & $4.0 \pm 0.08$ & $5.5 \pm 0.16$ & $14.0 \pm 0.59$ \\
\hline 11 & $8.2 \pm 0.41$ & $12.8 \pm 0.32$ & $4.1 \pm 0.06$ & $3.7 \pm 0.07$ & $9.6 \pm 0.36$ \\
\hline 12 & $7.4 \pm 0.34$ & $9.4 \pm 0.19$ & $2.4 \pm 0.04$ & $10.0 \pm 0.19$ & $4.0 \pm 0.13$ \\
\hline \multicolumn{6}{|c|}{$\left[\mathrm{Au}(\mathrm{SPyCOOH})\left(\mathrm{PR}_{3}\right)\right], \mathrm{R}=$ amino acid } \\
\hline 13 & $14.7 \pm 0.88$ & $8.2 \pm 0.13$ & $7.6 \pm 0.11$ & $35.2 \pm 0.53$ & $25.9 \pm 1.04$ \\
\hline 14 & $7.7 \pm 0.22$ & $10.7 \pm 0.16$ & $3.7 \pm 0.06$ & $12.8 \pm 0.27$ & $6.1 \pm 0.18$ \\
\hline 15 & $14.7 \pm 0.20$ & $12.3 \pm 0.32$ & $4.3 \pm 0.08$ & $11.3 \pm 0.29$ & $6.5 \pm 0.25$ \\
\hline 16 & $15.9 \pm 0.50$ & $11.5 \pm 0.29$ & $6.7 \pm 0.13$ & $65.5 \pm 1.12$ & $33.1 \pm 1.13$ \\
\hline 17 & $14.1 \pm 0.55$ & $14.5 \pm 0.26$ & $3.6 \pm 0.06$ & $49.3 \pm 1.53$ & $28.4 \pm 1.16$ \\
\hline 18 & $14.3 \pm 0.61$ & $11.6 \pm 0.20$ & $7.5 \pm 0.07$ & $3.0 \pm 0.08$ & $4.0 \pm 0.11$ \\
\hline \multicolumn{6}{|c|}{$\left[\mathrm{Au}(\mathrm{SPyCOOH})\left(\mathrm{PR}_{3}\right)\right], \mathrm{R}=$ amide derivative of amino acid } \\
\hline 19 & $28.3 \pm 1.02$ & $27.2 \pm 0.65$ & $3.9 \pm 0.06$ & $14.4 \pm 0.42$ & $4.9 \pm 0.16$ \\
\hline 20 & $19.1 \pm 0.67$ & $8.1 \pm 0.23$ & $3.9 \pm 0.07$ & $8.1 \pm 0.28$ & $1.4 \pm 0.04$ \\
\hline 21 & $14.4 \pm 0.60$ & $12.5 \pm 0.32$ & $3.8 \pm 0.06$ & $7.6 \pm 0.26$ & $5.2 \pm 0.15$ \\
\hline 22 & $18.8 \pm 0.71$ & $14.1 \pm 0.29$ & $3.7 \pm 0.06$ & $14.6 \pm 0.57$ & $6.8 \pm 0.23$ \\
\hline 23 & $19.4 \pm 0.62$ & $15.2 \pm 0.33$ & $5.3 \pm 0.11$ & $13.6 \pm 0.40$ & $3.0 \pm 0.09$ \\
\hline 24 & $30.5 \pm 0.82$ & $19.2 \pm 0.36$ & $7.7 \pm 0.15$ & $5.8 \pm 0.16$ & $4.0 \pm 0.16$ \\
\hline \multicolumn{6}{|c|}{ Complexes obtained by structural modifications of $\left[\mathrm{Au}(\mathrm{SPyCOR})\left(\mathrm{PPh}_{3}\right)\right]$} \\
\hline 25 & $15.7 \pm 0.66$ & $17.4 \pm 0.48$ & $3.8 \pm 0.04$ & $12.0 \pm 0.19$ & $3.2 \pm 0.13$ \\
\hline 26 & $8.3 \pm 0.39$ & $13.1 \pm 0.26$ & $3.4 \pm 0.06$ & $3.5 \pm 0.11$ & $2.8 \pm 0.08$ \\
\hline 27 & $32.5 \pm 1.24$ & $29.3 \pm 0.70$ & $36.5 \pm 0.77$ & $>25$ & $10.4 \pm 0.35$ \\
\hline 28 & $18.7 \pm 0.64$ & $22.5 \pm 0.67$ & $8.6 \pm 0.14$ & $17.9 \pm 0.45$ & $15.4 \pm 0.60$ \\
\hline 29 & $33.5 \pm 1.31$ & $>50$ & NT & $8.3 \pm 0.19$ & $1.9 \pm 0.05$ \\
\hline 30 & $16.5 \pm 0.92$ & $17.1 \pm 0.39$ & $4.2 \pm 0.05$ & $7.7 \pm 0.24$ & $3.0 \pm 0.08$ \\
\hline 31 & $18.3 \pm 0.75$ & $15.1 \pm 0.27$ & $3.6 \pm 0.06$ & $>25$ & $1.2 \pm 0.02$ \\
\hline 32 & $>50$ & $>50$ & NT & $>25$ & $10.7 \pm 0.29$ \\
\hline 33 & $4.1 \pm 0.11$ & $1.2 \pm 0.04$ & $0.9 \pm 0.07$ & $4.5 \pm 0.14$ & $0.8 \pm 0.02$ \\
\hline Cisplatin & $105 \pm 0.90$ & $71 \pm 0.80$ & $7.4 \pm 0.10$ & $14.0 \pm 0.20$ & $65.0 \pm 0.92$ \\
\hline
\end{tabular}

NT-Non tested; ${ }^{\text {aA549 }}$ = lung carcinoma, MiaPaca2 = pancreatic carcinoma, Jurkat = T-cell leukemia, R69 = lymphoid cell line and 293T = embryonic kidney fibroblasts.

A remarkable cytotoxic activity against the same human tumor cell lines (A549, Jurkat and MiaPaca2) was observed for the gold(I) complexes with cysteine-containing dipeptides 34-44 (Figure 3a and Table 3) [23]. Starting from the gold(I) complexes 34-39 of the general formula [Au(Boc-Cys-XOMe-S)(PPh $)](X=$ Gly, Ala, Val, Phe, Met and Pro; Boc = tert-butoxycarbonyl), different structural modifications of these complexes, such as changes in the phosphine ligand $\left(\mathrm{PPh}_{2} \mathrm{Py}\right.$ instead of $\left.\mathrm{PPh}_{3} ; 40\right)$, introducing new amino protecting group (benzyloxycarbonyl $(\mathrm{Z})$ 
instead of Boc; 41), the use of non-proteinogenic rigid octahydroindole methyl ester (OicOMe; 42) and increasing the number of $\mathrm{Au}(\mathrm{I})$ ions per complex unit (43 and 44), were performed in order to investigate the influence of these structural changes on the cytotoxicity of the gold(I) complexes with cysteine-containing dipeptides. As can be seen from Table 3, the $\mathrm{IC}_{50}$ values for the complexes 34-44 are in low micromolar range, from 1.5 to $15.6 \mu \mathrm{M}$ in $\mathrm{A} 549,0.4$ to $2.2 \mu \mathrm{M}$ in Jurkat and 0.1 to $5.4 \mu \mathrm{M}$ in MiaPaca2 cells, being much lower than the corresponding $\mathrm{IC}_{50}$ values for cisplatin $(105,7.4$ and 71 , respectively). The structural modifications leading to the formation of the complexes $\mathbf{4 0 - 4 2}$ (Figure 3a) resulted in almost similar activity against MiaPaca2 and A549 cells, while the introduction of an additional $\mathrm{Au}\left(\mathrm{PPh}_{3}\right)^{+}$moiety to the complex 34 led to the formation of complex 43 (Figure 3a), which is the most potent against MiaPaca2 cell line (Table 3). On the other hand, the coordination of two $\mathrm{Au}\left(\mathrm{PPh}_{3}\right)^{+}$fragments (complex 44, Figure 3a) did not significantly improve the cytotoxicity of the complex [23].

Table 3. In vitro cytotoxic activity ( $\left.\mathrm{IC}_{50}, \mathbf{2 4} \mathrm{h}, \mu \mathrm{M}\right)$ of gold(I) complexes 34-51 in A549, Jurkat and MiaPaca2 cell lines [23-25].

\begin{tabular}{|c|c|c|c|}
\hline Complex & A549 & MiaPaca2 & Jurkat \\
\hline \multicolumn{4}{|c|}{ Complexes with cysteine-containing dipeptides } \\
\hline 34 & $1.5 \pm 0.2$ & $2.0 \pm 0.2$ & $0.9 \pm 0.1$ \\
\hline 35 & $1.9 \pm 0.1$ & $1.9 \pm 0.1$ & $1.6 \pm 0.1$ \\
\hline 36 & $2.3 \pm 0.1$ & $3.0 \pm 0.1$ & $2.2 \pm 0.1$ \\
\hline 37 & $15.6 \pm 0.11$ & $5.4 \pm 0.1$ & $0.4 \pm 0.1$ \\
\hline 38 & $4.8 \pm 0.1$ & $1.8 \pm 0.1$ & $1.7 \pm 0.1$ \\
\hline 39 & $3.0 \pm 0.1$ & $0.7 \pm 0.1$ & $0.5 \pm 0.1$ \\
\hline 40 & $5.0 \pm 0.2$ & $0.5 \pm 0.1$ & $0.8 \pm 0.1$ \\
\hline 41 & $2.7 \pm 0.1$ & $1.5 \pm 0.1$ & $1.1 \pm 0.1$ \\
\hline 42 & $2.1 \pm 0.1$ & $1.2 \pm 0.1$ & $1.5 \pm 0.1$ \\
\hline 43 & $1.8 \pm 0.1$ & $0.1 \pm 0.1$ & $0.6 \pm 0.1$ \\
\hline 44 & $3.5 \pm 0.1$ & $1.5 \pm 0.1$ & $0.8 \pm 0.1$ \\
\hline \multicolumn{4}{|c|}{ Complexes with 4-mercaptoproline } \\
\hline 45 & $1.8 \pm 0.15$ & $3.0 \pm 0.19$ & $0.8 \pm 0.08$ \\
\hline 46 & $3.8 \pm 0.37$ & $6.1 \pm 0.54$ & $3.5 \pm 0.32$ \\
\hline 47 & $>25$ & $>25$ & $9.3 \pm 0.65$ \\
\hline 48 & $3.5 \pm 0.29$ & $2.3 \pm 0.22$ & $0.6 \pm 0.08$ \\
\hline 49 & $1.9 \pm 0.16$ & $1.8 \pm 0.17$ & $0.5 \pm 0.07$ \\
\hline \multicolumn{4}{|c|}{ Complexes with $N$,S-heterocyclic carbenes } \\
\hline 50 & $0.4 \pm 0.01$ & $16.6 \pm 0.2$ & $6.2 \pm 0.1$ \\
\hline 51 & $>25$ & $24.8 \pm 0.1$ & ca. 25 \\
\hline Cisplatin & $105 \pm 0.90$ & $71 \pm 0.80$ & $7.4 \pm 0.10$ \\
\hline
\end{tabular}


a)<smiles>CC(=O)CNC(=O)C(CSCC(=O)O)NC(=O)c1ccccc1</smiles>

[Au(Boc-Cys-GlyOMe-S)(PPh 3 )] (34)<smiles>CC(=O)C(Cc1ccccc1)NC(=O)C(CSCCNCc1ccccc1)NCc1ccccc1</smiles>

[Au(Boc-Cys-PheOMe-S) $\left.\left(\mathrm{PPh}_{3}\right)\right](37)$<smiles>CC(=O)C(C)NC(=O)C(CSCCNC(=O)c1ccccc1)NC(=O)c1ccccc1</smiles>

[Au(Boc-Cys-AlaOMe-S) $\left.\left(\mathrm{PPh}_{3}\right)\right]$ (35)

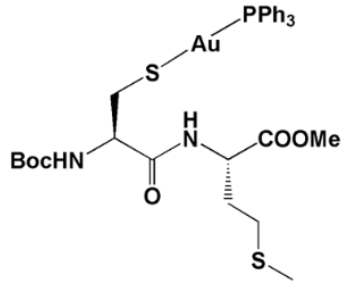

[Au(Boc-Cys-MetOMe-S) $\left.\left(\mathrm{PPh}_{3}\right)\right]$ (38)<smiles>CC(=O)C(NC(=O)C(CSCNC(=O)c1ccccc1)NC(=O)c1ccccc1)C(C)C</smiles>

[Au(Boc-Cys-ValOMe-S) $\left.\left(\mathrm{PPh}_{3}\right)\right](36)$

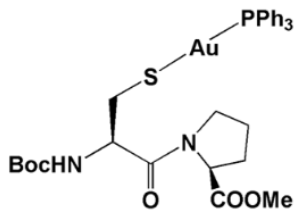

[Au(Boc-Cys-ProOMe-S) $\left.\left(\mathrm{PPh}_{3}\right)\right]$ (39)

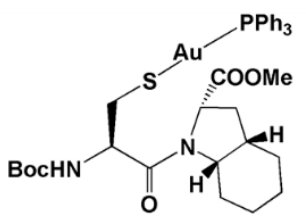

$\left[\mathrm{Au}(\mathrm{Boc}-\mathrm{Cys}-\mathrm{GlyOMe}-\mathrm{S})\left(\mathrm{PPh}_{2} \mathrm{Py}\right)\right](\mathbf{4 0}) \quad\left[\mathrm{Au}(\mathrm{Z}-\mathrm{Cys}-\mathrm{GlyOMe-S})\left(\mathrm{PPh}_{3}\right)\right](\mathbf{4 1}) \quad\left[\mathrm{Au}\left(\mathrm{Boc}_{1} \quad \mathrm{Cys}-\mathrm{OicOMe}-\mathrm{S}\right)\left(\mathrm{PPh}_{3}\right)\right](\mathbf{4 2})$

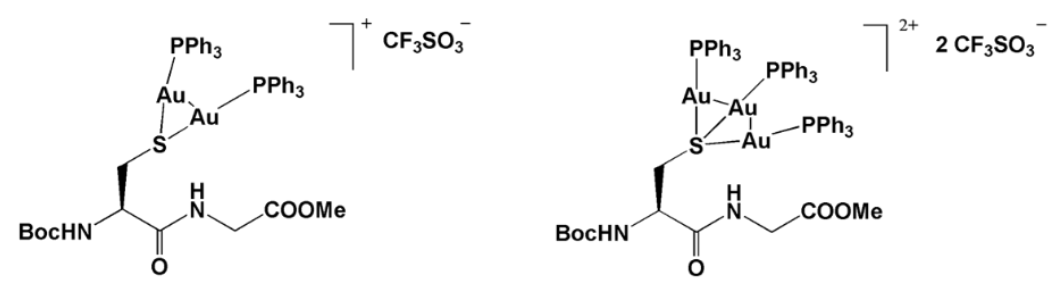

$\left[\mathrm{Au}_{2}(\mathrm{Boc}-\mathrm{Cys}-\mathrm{GlyOMe}-\mathrm{S})\left(\mathrm{PPh}_{3}\right)_{2}\right] \mathrm{CF}_{3} \mathrm{SO}_{3}(\mathbf{4 3}) \quad\left[\mathrm{Au}_{3}(\mathrm{Boc}-\mathrm{Cys}-\mathrm{GlyOMe}-\mathrm{S})\left(\mathrm{PPh}_{3}\right)_{3}\right]\left(\mathrm{CF}_{3} \mathrm{SO}_{3}\right)_{2}(\mathbf{4 4})$

b)

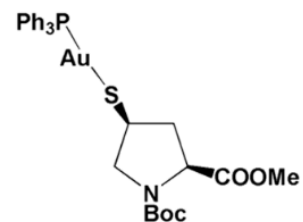

$\left[\mathrm{Au}(\mathrm{Boc}-\mathrm{Pro}(\mathrm{SH}) \mathrm{OMe}-\mathrm{S})\left(\mathrm{PPh}_{3}\right)\right](\mathbf{4 5})$

$\mathrm{Ph}_{3} \mathrm{P}$

Au

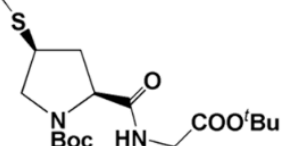

$\left[\mathrm{Au}\left(\mathrm{Boc}-\mathrm{Pro}(\mathrm{SH}) \mathrm{GlyO}{ }^{t} \mathrm{Bu}-\mathrm{S}\right)\left(\mathrm{PPh}_{3}\right)\right](\mathbf{4 8})$
$\mathrm{PyPh}_{2} \mathrm{P}$

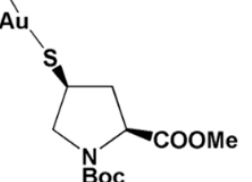

$\mathrm{Ph}_{3} \mathrm{P}$

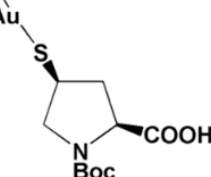

[Au(Boc-Pro(SH)OMe-S)(PPh $\left.\left.{ }_{2} \mathrm{Py}\right)\right](46)$

[Au(Boc-Pro(SH)OH-S)( $\left.\left.\mathrm{PPh}_{3}\right)\right](47)$

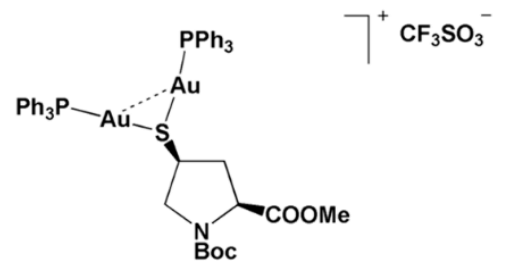

$\left[\mathrm{Au}_{2}(\mathrm{Boc}-\mathrm{Pro}(\mathrm{SH}) \mathrm{OMe}-\mathrm{S})\left(\mathrm{PPh}_{3}\right)_{2}\right] \mathrm{CF}_{3} \mathrm{SO}_{3}(49)$

Figure 3. (a) Gold(I) complexes with cysteine-containing dipeptides 34-44 [23] and (b) with non-proteinogenic 4-mercaptoproline amino acid 45-49 [24] showing antiproliferative activity. 
Similar cytotoxic activity to the gold(I) complexes with cysteine-containing dipeptides $\mathbf{3 4 - 4 4}$ was manifested by the gold(I) complexes bearing non-proteinogenic 4-mercaptoproline amino acid (45-49, Figure 3b and Table 3) [24]. This amino acid is a hybrid of proline and homocysteine, and has the properties of both amino acids, nucleophilic character and reducing properties of the thiol group of homocysteine and rigid structure of proline. N-Protected 4-mercaptoproline ester was reacted with $\left[\mathrm{AuCl}\left(\mathrm{PR}_{3}\right)\right]$ to yield $\left[\mathrm{Au}(\mathrm{Boc}-\mathrm{Pro}(\mathrm{SH}) \mathrm{OMe}-\mathrm{S})\left(\mathrm{PR}_{3}\right)\right]$ complexes $\left(\mathrm{PR}_{3}=\mathrm{PPh}_{3}\right.$ (45) and $\left.\mathrm{PPh}_{2} \mathrm{Py}(46)\right)$, while $\left[\mathrm{Au}(\mathrm{Boc}-\mathrm{Pro}(\mathrm{SH}) \mathrm{OH}-\mathrm{S})\left(\mathrm{PPh}_{3}\right)\right]$ complex (47) was obtained after the basic hydrolysis of the amino ester moiety in 45 . The latter complex could be further transformed to the [Au(Boc-Pro(SH)-GlyO $\left.\left.{ }^{t} \mathrm{Bu}-\mathrm{S}\right)\left(\mathrm{PPh}_{3}\right)\right]$ complex (48), while the reaction of 45 with $\left[\mathrm{Au}\left(\mathrm{CF}_{3} \mathrm{SO}_{3}\right)\left(\mathrm{PPh}_{3}\right)\right]$ afforded the dinuclear $\left[\mathrm{Au}_{2}\right.$ (Boc-Pro(SH)OMe-S) $\left.\left(\mathrm{PPh}_{3}\right)_{2}\right] \mathrm{CF}_{3} \mathrm{SO}_{3}$ complex (49) (Figure 3b). As with the case of the abovementioned complexes, the antiproliferative activity of 45-49 is mainly due to the $\mathrm{Au}(\mathrm{I})$ center. The role of the phosphine ligand is to stabilize this metal ion and to enhance the lipophilicity, allowing the crossing through the membrane, while the thiolate takes part in the substitution reactions with the biomolecules and has an influence on the complex transport or biodistribution [24]. The gold(I) complexes 45, 46, 48 and 49 showed an excellent cytotoxic activity in the investigated human tumor cell lines (A549, Jurkat and MiaPaca2), with $\mathrm{IC}_{50}$ values being lower than $6.1 \mu \mathrm{M}$ and, in some cases, in the nanomolar range (Table 3). Complex 45 is found to be 100, 23 and 10-fold more active than cisplatin in A549, MiaPaca2 and Jurkat cell lines, respectively, and approximately 2-fold more active than its analogue 46, which contains $\mathrm{PPh}_{2} \mathrm{Py}$ ligand instead of $\mathrm{PPh}_{3}$. Similar to the abovementioned gold(I) complexes containing a thiolate ligand functionalized with several amino acids or peptide moieties [21], the formation of the complex with 4-mercaptoproline acid (47) decreased significantly the cytotoxic activity, probably as the consequence of higher lipophilicity of the ester group or higher reactivity of carboxylic group, preventing the complex to reach its target [24]. On the other hand, complex 48 with a dipeptide containing 4-mercaptoproline and dinuclear complex 49 have the antiproliferative activity at similar extent to the parent complex 45.

Two gold(I) complexes $\mathbf{5 0}$ and $\mathbf{5 1}$ with $\mathrm{N}$,S-heterocyclic carbenes derived from the peptides containing L-thiazolylalanine (Thz-Ala) showed good cytotoxic activity in vitro against the A549, MiaPaca2 and Jurkat cell lines (Figure 4a and Table 3) [25]. The carbene complex 50 with iodide was more efficient in all tested cell lines in respect to the thiolate-containing complex 51, what can be the consequence of the higher lability of $\mathrm{Au}-\mathrm{I}$ bond in respect to the $\mathrm{Au}-\mathrm{S}$ bond and higher lipophilicity of 50. As can be seen from Table 3, the $\mathrm{IC}_{50}$ values of $\mathbf{5 1}$ in A549 cell line was higher than $25 \mu \mathrm{M}$ and approximately $25 \mu \mathrm{M}$ for the remaining two cells, while $\mathbf{5 0}$ showed an excellent cytotoxicity against the $\mathrm{A} 549$ cell line with the $\mathrm{IC}_{50}$ value being in the submicromolar range.

The phenylalanine- $N$-heterocyclic carbene gold(I) complex 52 and its amino acid and dipeptide derivatives $\mathbf{5 3}$ and 54, respectively, were evaluated for their in vitro cytotoxic potential against the human cell lines HeLa (human cervix carcinoma), HT-29 (human caucasian colon adenocarcinoma grade II) and HepG2 (human hepatocellular liver carcinoma) (Figure $4 \mathrm{~b}$ and Table 4) [26]. These three complexes have shown moderate to good antiproliferative activity, with HeLa cells being the most sensitive. Among them, amino acid conjugate complex 53 exhibited the best activity, while the remaining two complexes showed a decrease in antitumor activity, which may be the consequence of differential uptake or different intracellular interactions [26]. 
a)<smiles></smiles>

50

b)<smiles>COC(=O)C(Cc1ccccc1)NC(=O)CN1C=CN(C(C)(C)C)C1[14CH](Cl)Cl</smiles>

52<smiles></smiles>

51

Figure 4. (a) Gold(I) complexes 50 and 51 with $N, S$-heterocyclic carbenes derived from the peptides containing L-thiazolylalanine [25] and (b) $N$-heterocyclic carbene gold(I) complexes 52-54 [26] showing antiproliferative activity.

Table 4. In vitro cytotoxic activity $\left(\mathrm{IC}_{50}, \mu \mathrm{M}\right)$ of $N$-heterocyclic carbene gold(I) complexes $\mathbf{5 2 - 5 4}$ in HeLa, HT-29 and HepG2 cell lines [26].

\begin{tabular}{ccccccc}
\hline \multirow{2}{*}{ Cell Line } & \multicolumn{2}{c}{ HeLa } & \multicolumn{2}{c}{ HepG2 } & \multicolumn{2}{c}{ HT-29 } \\
\cline { 2 - 7 } Complex & CV $^{\text {a }}$ & Resazurin & CV & Resazurin & CV & Resazurin \\
\hline $\mathbf{5 2}$ & $45.5 \pm 4.8$ & $52.7 \pm 5.0$ & $61.4 \pm 7.4$ & $71.3 \pm 5.9$ & $63.8 \pm 6.7$ & $58.9 \pm 4.3$ \\
$\mathbf{5 3}$ & $3.4 \pm 1.3$ & $8.3 \pm 1.4$ & $15.2 \pm 1.7$ & $20.4 \pm 0.9$ & $10.5 \pm 1.9$ & $16.9 \pm 1.7$ \\
$\mathbf{5 4}$ & $17.3 \pm 3$ & $29.4 \pm 1.8$ & $28.1 \pm 4.5$ & $30.0 \pm 2.6$ & $26.8 \pm 2.1$ & $34.6 \pm 1.8$ \\
\hline \multicolumn{3}{c}{${ }^{a}$ CV = crystal violet. }
\end{tabular}

\section{Gold(III) Complexes Containing Amino Acids and Peptides Moieties}

The abovementioned ferrocene bioconjugate, $\mathrm{FcCO}-\mathrm{MetOMe}$, was also used for the synthesis of gold(III) species, $\left[\mathrm{Au}(\mathrm{FcCO}-\mathrm{MetOMe}-\mathrm{S})\left(\mathrm{C}_{6} \mathrm{~F}_{5}\right)_{3}\right](55$; Figure 5), which was evaluated for in vitro cytotoxicity [19]. The $\mathrm{IC}_{50}$ values determined for this complex of $87 \pm 2.0,88 \pm 2.2$ and $31 \pm 2.4 \mu \mathrm{M}$ in HeLa, MCF-7 and N1E-115 cell lines, respectively, are higher than the corresponding values for the gold(I) complexes with the ferrocene bioconjugates and phosphine ligands $\left(\mathrm{PPh}_{3}\right.$ and $\left.\mathrm{PPh}_{2} \mathrm{Py}\right)$ (Table 1), indicating that the presence of a phosphine ligand is important for enhancement of cytotoxic potential of gold complexes [19].

A decrease in the antiproliferative activity after oxidation of $\mathrm{Au}(\mathrm{I})$ to $\mathrm{Au}(\mathrm{III})$ was also observed for the phenylalanine- $N$-heterocyclic carbene gold(III) complex 56 (Figure 5) in HT-29 cell line $\left(\mathrm{IC}_{50}=125.8 \pm 49.7\right.$ and $282.5 \pm 41.8 \mu \mathrm{M}$ determined by crystal violet and resazurin assays, respectively) [26]. 


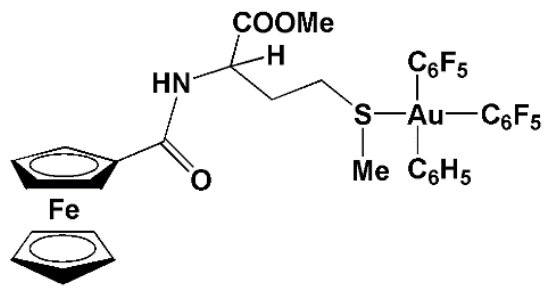

55

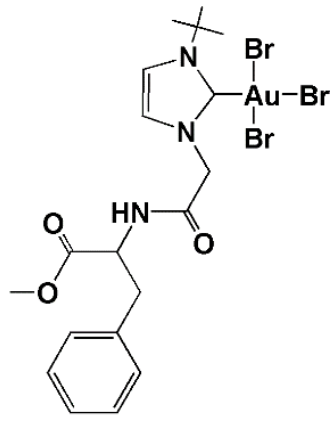

56

Figure 5. Structural formulas of gold(III) complexes 55 [19] and 56 [26], showing a decrease in the antiproliferative potential in comparison to the analogue gold(I) species.

With the aim to obtain gold(III)-based peptidomimetics with anticancer properties that could target two peptide transporters, PEPT1 and PEPT2, which are upregulated in some tumor cells, Fregona et al. synthesized the complexes of the general formula $\left[\mathrm{AuX} \mathrm{X}_{2}\left(\mathrm{dtc}-\mathrm{Sar}-\mathrm{AA}-\mathrm{O}^{t} \mathrm{Bu}\right)\right]$ (dtc = dithiocarbamate; $\mathrm{AA}=\mathrm{Gly}, \mathrm{X}=\mathrm{Br}^{-}$(57)/Cl- (58); $\mathrm{AA}=\mathrm{Aib}$ (2-aminoisobutyric acid), $\mathrm{X}=\mathrm{Br}^{-}$(59)/Cl- (60); $\mathrm{AA}=\mathrm{L}-\mathrm{Phe}$, $\mathrm{X}=\mathrm{Br}^{-}(\mathbf{6 1}) / \mathrm{Cl}^{-}(\mathbf{6 2})$ ) (Figure 6) [27]. The in vitro cytotoxicity of these complexes was evaluated toward the human androgen receptor-negative prostate cancer PC3 and DU145 cells, ovarian adenocarcinoma 2008 cells and the cisplatin-resistant C13 cell line, and Hodgkin's lymphoma L540 cells over 72 h, while cisplatin was used as a reference (Table 5). Among these complexes, $\mathbf{6 1}$ and $\mathbf{6 2}$ were less active, with the $\mathrm{IC}_{50}$ values higher than cisplatin (except $\mathrm{C} 13$ cell line), indicating that an aromatic or highly hydrophobic fragment attached to sarcosine decreases the cytotoxicity of the gold(III) complex. On the other hand, complexes 57-60 were generally more efficient than cisplatin, with Aib-containing complex 59 being the most active towards the investigated tumor cell lines (Table 5). Importantly, 59 showed 30-fold higher activity than cisplatin in growth inhibition of cisplatin-resistant ovarian adenocarcinoma $\mathrm{C} 13$ cells, excluding the occurrence of cross-resistance. Both the most active Aib-containing complexes 59 and 60 exerted their cytotoxic activity within the first $24 \mathrm{~h}$, while the activity of the cisplatin significantly increased with the increasing of the exposure time [27]. The fact that the two most active complexes contain 2-aminoisobutyric acid is not surprising, since this amino acid is abundant in a class of peptide antibiotics, showing anticancer and antiviral properties [28,29]. Moreover, this amino acid plays a crucial role in the biological activity of peptide antibiotics, by forcing the peptide backbone to fold into helical arrangements and providing a capability to cross and/or perturb cell membranes [30]. Apoptosis was shown to be the major mechanism of cell death in the case of prostate cancer PC3 and DU145 cells and ovarian adenocarcinoma C13 cells, for the most active complexes 59 and 60, while, in the case of the cisplatin-sensitive 2008 cells and the Hodgkin's lymphoma L540 cell line, the majority of dead cells underwent late apoptosis/necrosis over $24 \mathrm{~h}$, after exposure to the these complexes [27]. On the other hand, the remaining gold(III) complexes and cisplatin were less effective in inducing apoptosis. 


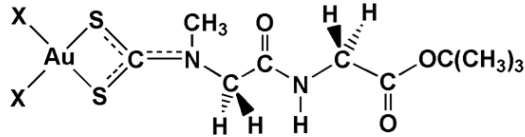

[AuX 2 (dtc-Sar-Gly-OtBu)] $\mathrm{X}=\mathrm{Br}^{-}(57) / \mathrm{Cl}^{-}(58)$<smiles>[X][X]1([X])S[C](N(C)CC(=O)NN([CH])C(C)(C)C(=O)OC(C)(C)C)S1</smiles>

[AuX ${ }_{2}$ (dtc-Sar-Aib-Ot Bu)] $\mathrm{X}=\mathrm{Br}^{-}(59) / \mathrm{Cl}^{-}(\mathbf{6 0})$<smiles>[X][X]1([X])SC(N(C)[C@H]([2H])C(=O)N[C@@H](Cc2ccccc2)C(=O)OCC)=[SH]1</smiles>

[AuX 2 (dtc-Sar-L-Phe-O $\left.{ }^{t} \mathrm{Bu}\right)$ ] $\mathrm{X}=\mathrm{Br}^{-}(61) / \mathrm{Cl}^{-}(62)$<smiles>[X][X]1([X])SC(N(C)[C@@H]([2H])C(=O)NC(COC(C)(C)C)C(=O)OC(C)(C)C)=[SH]1</smiles>

[Au(dtc-Sar-L-Ser( $\left.(t-\mathrm{Bu})-\mathrm{O}(t-\mathrm{Bu})) \mid \mathrm{X}_{2}\right]$ $\mathrm{X}=\mathrm{Br}^{-}(63), \mathrm{Cl}^{-}(64)$<smiles></smiles>

[Au(dtc-D, L-Pro-Aib $\left.2-\mathrm{O}(t-B u)) \mathrm{X}_{2}\right]$ $\mathrm{X}=\mathrm{Br}^{-}(67), \mathrm{Cl}^{-}(68)$<smiles>[X][X]1([X])SC(N(C)CC(=O)NC(C)(C)C(=O)NC(C)(C)C(=O)OC(C)(C)C)=[SH]1</smiles>

[Au(dtc-Sar-Aib $\left.2-\mathrm{O}(t-\mathrm{Bu})) \mathrm{X}_{2}\right]$ $\mathrm{X}=\mathrm{Br}^{-}(65), \mathrm{Cl}^{-}(66)$<smiles>[X][X]1([X])S[C](N(C)CC(=O)NC(C)(C)C(=O)NC(C)(C)C(=O)N([2H])C(C)(C)C(=O)OC(C)(C)C)S1</smiles>

$\left[\mathrm{Au}\left(\mathrm{dtc}-\mathrm{Sar}-\mathrm{Aib} \mathrm{b}_{3}-\mathrm{O}(t-\mathrm{Bu})\right) \mathrm{X}_{2}\right]$ $\mathrm{X}=\mathrm{Br}^{-}(\mathbf{6 9}), \mathrm{Cl}^{-}(\mathbf{7 0})$<smiles>[X][X]1([X])SC(N(C)CC(=O)NC(C)(C)C(=O)NC(C)(C)C(=O)N([CH])C(C)(C)C(=O)NCC(=O)OC(C)=O)=[SH]1</smiles>

[Au(dtc-Sar-Aib $\left.\left.{ }_{3}-\mathrm{Gly}-\mathrm{OEt}\right) \mathrm{X}_{2}\right]$

$$
\mathrm{X}=\mathrm{Br}^{-}(71), \mathrm{Cl}^{-}(72)
$$

Figure 6. Gold(III)-dithiocarbamato derivatives of oligopeptides 57-72 showing antiproliferative activity $[27,31]$.

The same group of authors further synthesized the gold(III)-dithiocarbamato derivatives of oligopeptides, $\left.\left[\mathrm{AuX} \mathrm{X}_{2}\left(\mathrm{dtc}-\mathrm{Sar}-\mathrm{L}-\mathrm{Ser}\left({ }^{t} \mathrm{Bu}\right)-\mathrm{O}^{t} \mathrm{Bu}\right)\right)\right]\left(\mathrm{X}=\mathrm{Br}^{-}(63) / \mathrm{Cl}^{-}(64)\right),\left[\mathrm{AuX}_{2}\left(\mathrm{dtc}-\mathrm{AA}-\mathrm{Aib}_{2}-\mathrm{O}^{t} \mathrm{Bu}\right)\right]$ $\left(\mathrm{AA}=\mathrm{Sar}\right.$ (sarcosine, $N$-methylglycine), $\mathrm{X}=\mathrm{Br}^{-}(65) / \mathrm{Cl}^{-}$(66), $\mathrm{AA}=\mathrm{D}, \mathrm{L}-\mathrm{Pro}, \mathrm{X}=\mathrm{Br}^{-}(67) / \mathrm{Cl}^{-}(68)$ ), $\left[\mathrm{AuX} \mathrm{X}_{2}\left(\mathrm{dtc}-\mathrm{Sar}-\mathrm{Aib}_{3}-\mathrm{O}^{t} \mathrm{Bu}\right)\right]\left(\mathrm{X}=\mathrm{Br}^{-}(69) / \mathrm{Cl}^{-}(70)\right)$, and $\left[\mathrm{AuX} \mathrm{X}_{2}\left(\mathrm{dtc}-\mathrm{Sar}-\mathrm{Aib}_{3}-\mathrm{Gly}-\mathrm{OEt}\right)\right]\left(\mathrm{X}=\mathrm{Br}^{-}(71) / \mathrm{Cl}^{-}\right.$ (72)) (Figure 6) and evaluated their cytotoxic activity toward four different cell lines (PC3, 2008, C13 and L540; Table 5) [31].

The $\mathrm{IC}_{50}$ values of the complexes determined after the exposure of L540 cells to the complexes 63-72 are in the range 1.4-5.4 $\mu \mathrm{M}$, being similar to the corresponding value for cisplatin of $2.5 \mu \mathrm{M}$. The gold(III) complexes 63-68 showed antiproliferative activity comparable to or lower than cisplatin on 
prostate cancer and ovarian adenocarcinoma cells, while the tetra- and pentapeptide derivatives 69-72 appeared to be less effective. However, against the cisplatin-resistant C13 cell line, all these gold(III) complexes were much more active than cisplatin (Table 5). Among the complexes 63-72, 68 containing proline and 2-aminoisobutiric acid turned out to be the most active toward all the investigated tumor cell lines, having the $\mathrm{IC}_{50}$ values comparable to the abovementioned complex 59 [27,31].

Table 5. In vitro cytotoxic activity $\left(\mathrm{IC}_{50}, \mu \mathrm{M}, 72 \mathrm{~h}\right.$ ) of the gold(III)-dithiocarbamato derivatives of oligopeptides $\mathbf{5 7 - 7 2}$ against different tumor cell lines [27,31].

\begin{tabular}{|c|c|c|c|c|c|}
\hline Cell Line ${ }^{a}$ & PC3 & DU145 & 2008 & C13 & L540 \\
\hline \multicolumn{6}{|c|}{$\left[\mathrm{AuX}{ }_{2}\left(\mathrm{dtc}-\mathrm{Sar}-\mathrm{AA}-\mathrm{O}^{t} \mathrm{Bu}\right)\right] \mathrm{AA}=\mathrm{Gly}, \mathrm{X}=\mathrm{Br}^{-}(57) / \mathrm{Cl}^{-}$(58); Aib, $\mathrm{X}=\mathrm{Br}^{-}(59) / \mathrm{Cl}^{-}(\mathbf{6 0}) ; \mathrm{L}-\mathrm{Phe}, \mathrm{X}=\mathrm{Br}^{-}(\mathbf{6 1}) / \mathrm{Cl}^{-}(\mathbf{6 2})$} \\
\hline 57 & $1.3 \pm 0.1$ & $4.5 \pm 0.9$ & $18.0 \pm 1.6$ & $11.5 \pm 1.2$ & $2.1 \pm 0.2$ \\
\hline 58 & $1.6 \pm 0.1$ & $2.5 \pm 0.3$ & $13.2 \pm 1.1$ & $15.9 \pm 1.3$ & $3.4 \pm 0.2$ \\
\hline 59 & $0.8 \pm 0.1$ & $1.4 \pm 0.1$ & $4.5 \pm 0.2$ & $3.7 \pm 0.3$ & $1.5 \pm 0.2$ \\
\hline 60 & $1.1 \pm 0.1$ & $2.2 \pm 0.1$ & $4.7 \pm 0.2$ & $5.1 \pm 0.4$ & $1.7 \pm 0.3$ \\
\hline 61 & $16.8 \pm 1.7$ & $13.2 \pm 1.2$ & $41.2 \pm 4.0$ & $17.2 \pm 1.8$ & $16.4 \pm 1.5$ \\
\hline 62 & $16.5 \pm 1.6$ & $15.3 \pm 1.5$ & $43.4 \pm 3.8$ & $21.5 \pm 1.5$ & $7.3 \pm 0.5$ \\
\hline \multicolumn{6}{|c|}{$\left.\left[\mathrm{AuX}{ }_{2}\left(\mathrm{dtc}-\mathrm{Sar}-\mathrm{L}-\mathrm{Ser}\left({ }^{t} \mathrm{Bu}\right)-\mathrm{O}^{t} \mathrm{Bu}\right)\right)\right] \mathrm{X}=\mathrm{Br}^{-}(63) / \mathrm{Cl}^{-}(64)$} \\
\hline 63 & $5.2 \pm 0.5$ & NT & $17.5 \pm 1.6$ & $17.0 \pm 1.6$ & $3.4 \pm 0.2$ \\
\hline 64 & $6.5 \pm 0.7$ & NT & $15.2 \pm 1.5$ & $16.1 \pm 1.3$ & $1.4 \pm 0.1$ \\
\hline \multicolumn{6}{|c|}{$\left[\mathrm{AuX}{ }_{2}\left(\mathrm{dtc}-\mathrm{AA}-\mathrm{Aib}_{2}-\mathrm{O}^{t} \mathrm{Bu}\right)\right] \mathrm{AA}=\mathrm{Sar}, \mathrm{X}=\mathrm{Br}^{-}(65) / \mathrm{Cl}^{-}(66) ; \mathrm{D}, \mathrm{L}-\mathrm{Pro}, \mathrm{X}=\mathrm{Br}^{-}(67) / \mathrm{Cl}^{-}(68)$} \\
\hline 65 & $5.8 \pm 0.6$ & NT & $12.0 \pm 1.1$ & $15.0 \pm 1.3$ & $3.8 \pm 0.4$ \\
\hline 66 & $5.8 \pm 0.5$ & NT & $14.2 \pm 1.5$ & $15.4 \pm 1.4$ & $4.1 \pm 0.5$ \\
\hline 67 & $6.3 \pm 0.7$ & NT & $16.3 \pm 1.4$ & $11.5 \pm 1.1$ & $2.2 \pm 0.1$ \\
\hline 68 & $3.0 \pm 0.2$ & NT & $8.2 \pm 0.7$ & $7.8 \pm 0.5$ & $2.2 \pm 0.2$ \\
\hline \multicolumn{6}{|c|}{$\left[\mathrm{AuX}{ }_{2}\left(\mathrm{dtc}-\mathrm{Sar}-\mathrm{Aib}_{3}-\mathrm{O}^{t} \mathrm{Bu}\right)\right] \mathrm{X}=\mathrm{Br}^{-}(69) / \mathrm{Cl}^{-}(70)$} \\
\hline 69 & $16.0 \pm 1.7$ & NT & $42.8 \pm 4.1$ & $17.5 \pm 1.6$ & $3.9 \pm 0.4$ \\
\hline 70 & $16.1 \pm 0.6$ & NT & $43.5 \pm 1.2$ & $11.5 \pm 1.2$ & $3.5 \pm 0.2$ \\
\hline \multicolumn{6}{|c|}{$\left[\mathrm{AuX}_{2}\left(\mathrm{dtc}-\mathrm{Sar}-\mathrm{Aib}_{3}-\mathrm{Gly}-\mathrm{OEt}\right)\right] \mathrm{X}=\mathrm{Br}^{-}(71) / \mathrm{Cl}^{-}(72)$} \\
\hline 71 & $15.0 \pm 1.4$ & NT & $29.2 \pm 3.0$ & $22.9 \pm 1.9$ & $5.4 \pm 0.5$ \\
\hline 72 & $20.0 \pm 1.9$ & NT & $27.8 \pm 2.3$ & $35.5 \pm 3.9$ & $5.0 \pm 0.8$ \\
\hline Cisplatin & $3.3 \pm 0.3$ & $4.5 \pm 0.1$ & $19.4 \pm 1.2$ & $117.2 \pm 9.1$ & $2.5 \pm 0.1$ \\
\hline
\end{tabular}

NT-Non tested; ${ }^{a}$ PC3 and DU145 cells = the human androgen receptor-negative prostate cancer cells, 2008 cells $=$ ovarian adenocarcinoma and C13 = the parent cisplatin-resistant cell line, L540 = Hodgkin's lymphoma.

Seven gold(III) complexes with different L-histidine-containing dipeptides, $\left[\mathrm{Au}\left(\mathrm{Gly}-\mathrm{L}-\mathrm{His}-\mathrm{N}_{A}, N_{P}, \mathrm{~N} 3\right) \mathrm{Cl}\right] \mathrm{Cl} .3 \mathrm{H}_{2} \mathrm{O} \quad$ (73), $\quad\left[\mathrm{Au}\left(\right.\right.$ Gly-L-His- $\left.\left.\mathrm{N}_{A}, \mathrm{~N}_{P}, \mathrm{~N} 3\right) \mathrm{Cl}\right] \mathrm{NO}_{3} \cdot 1.25 \mathrm{H}_{2} \mathrm{O}$ (74), [Au(L-Ala-L-His- $\left.N_{A}, N_{P}, N 3\right) \mathrm{Cl}^{2} \mathrm{NO}_{3} \cdot 2 \cdot 5 \mathrm{H}_{2} \mathrm{O}$ (75), [Au(L-Ala-L-His- $\left.\left.\mathrm{N}_{A}, \mathrm{~N}_{P}, \mathrm{~N} 3\right) \mathrm{Cl}\right]\left[\mathrm{AuCl}_{4}\right] \cdot \mathrm{H}_{2} \mathrm{O}$ (76), [Au(L-Val-L-His- $\left.\left.N_{A}, N_{P}, N 3\right) \mathrm{Cl}\right] \mathrm{Cl} \cdot 2 \mathrm{H}_{2} \mathrm{O}$ (77), [Au(L-Leu-L-His- $\left.\left.N_{A}, N_{P}, N 3\right) \mathrm{Cl}\right] \mathrm{Cl}$ (78) and $\left[\mathrm{Au}\left(\mathrm{L}-\mathrm{Leu}-\mathrm{L}-\mathrm{His}-\mathrm{N}_{A}, N_{P}, \mathrm{~N} 3\right) \mathrm{Cl}\right]\left[\mathrm{AuCl}_{4}\right] \cdot \mathrm{H}_{2} \mathrm{O}(79)$ were evaluated for in vitro cytotoxicity against different human tumor cell lines (Figure 7 and Table 6) [32-34]. Different spectroscopic techniques confirmed that tridentate coordination of the X-L-His dipeptides (X = Gly, L-Ala, L-Val and L-Leu) through the N3 imidazole nitrogen (N3), deprotonated nitrogen of the amide bond $\left(N_{P}\right)$ and to the nitrogen of the $N$-terminal amino group $\left(N_{A}\right)$ stabilized +3 oxidation state of gold, preventing its reduction to $\mathrm{Au}(\mathrm{I}) / \mathrm{Au}(0)$ under physiological conditions. Firstly, complex 73 was tested against the tumor cell line A2780 (human ovarian carcinoma), both sensitive (A2780/S) and resistant (A2780/R) to cisplatin [32]. This complex exhibited a remarkable antiproliferative activity against A2780/S cell line $\left(\mathrm{IC}_{50}=5.2 \pm 1.63 \mu \mathrm{M}\right)$, being slightly less active than cisplatin $\left(\mathrm{IC}_{50}=1.6 \pm 0.58 \mu \mathrm{M}\right)$. Importantly, the complex retains a significant cytotoxicity on the A2780/R cell line $\left(\mathrm{IC}_{50}=8.5 \pm 2.3 \mu \mathrm{M}\right)$, having the resistance factor of only 1.6. The results of this study also showed that the $\mathrm{Zn}(\mathrm{II}), \mathrm{Pd}(\mathrm{II})$, $\mathrm{Pt}(\mathrm{II})$ and $\mathrm{Co}(\mathrm{II})$ complexes with the same dipeptide manifested only modest activity toward A2780/S and A2780/R cell lines, confirming that the presence of $\mathrm{Au}(\mathrm{III})$ ion was crucial for the cytotoxic effects [32]. 


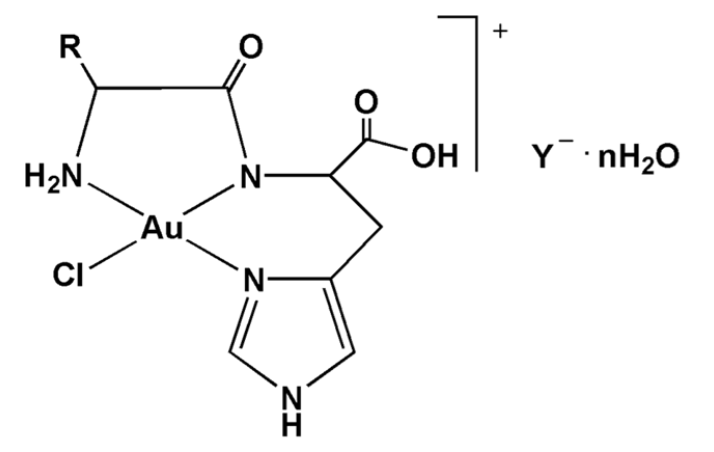

\begin{tabular}{|c|c|c|c|c|}
\hline $\begin{array}{c}\text { Gold(III) } \\
\text { complex }\end{array}$ & $\mathbf{X}$ & $\mathbf{R}$ & $\mathbf{Y}$ & $\mathbf{n}$ \\
\hline 73 & $\mathbf{G l y}$ & $\mathbf{H}$ & $\mathrm{Cl}^{-}$ & $\mathbf{3}$ \\
\hline 74 & $\mathbf{G l y}$ & $\mathbf{H}$ & $\mathrm{NO}_{3}^{-}$ & $\mathbf{1 . 2 5}$ \\
\hline 75 & L-Ala & $\mathrm{CH}_{3}$ & $\mathrm{NO}_{3}^{-}$ & $\mathbf{2 . 5}$ \\
\hline 76 & L-Ala & $\mathrm{CH}_{3}$ & {$\left[\mathrm{AuCl}_{4}\right]^{-}$} & $\mathbf{1}$ \\
\hline 77 & L-Val & $\left.\mathrm{CH}^{-} \mathrm{CH}_{3}\right)_{2}$ & $\mathrm{Cl}^{-}$ & $\mathbf{2}$ \\
\hline 78 & L-Leu & $\mathrm{CH}_{2} \mathrm{CH}\left(\mathrm{CH}_{3}\right)_{2}$ & $\mathrm{Cl}^{-}$ & $\mathbf{0}$ \\
\hline 79 & L-Leu & $\mathrm{CH}_{2} \mathrm{CH}\left(\mathrm{CH}_{3}\right)_{2}$ & {$\left[\mathrm{AuCl}_{4}\right]^{-}$} & $\mathbf{1}$ \\
\hline
\end{tabular}

\section{[Au(X-L-His- $\left.\left.N_{A}, N_{R} N 3\right) C l\right] Y \cdot \mathrm{nH}_{2} \mathrm{O}$ \\ $73-79$}

Figure 7. Gold(III) complexes with L-histidine-containing dipeptides 73-79, which were evaluated for the in vitro cytotoxic potential [32-34].

Table 6. In vitro cytotoxic activity $\left(\mathrm{IC}_{50}, \mu \mathrm{M}\right)$ of gold(III) complexes with L-histidine-containing dipeptides 73-79 against different cell lines [32-34].

\begin{tabular}{|c|c|c|c|c|c|c|c|}
\hline Cell Line ${ }^{a}$ & MRC-5 & MCF-7 & HT-29 & HL-60 & Raji & HeLa & A549 \\
\hline 73 & $>200$ & & & & & 150 & 150 \\
\hline 74 & $>200$ & $19.68 \pm 0.23$ & $14.70 \pm 1.36$ & $11.93 \pm 1.02$ & $3.30 \pm 0.02$ & $>200$ & $>200$ \\
\hline 75 & $>200$ & $>100$ & $>100$ & $>100$ & $>100$ & 170 & 170 \\
\hline 76 & $150^{\mathrm{b}}$ & & & & & 75 & 30 \\
\hline 77 & $>200$ & & & & & $>200$ & $>200$ \\
\hline 78 & 170 & & & & & 55 & 115 \\
\hline 79 & 100 & & & & & 65 & 75 \\
\hline Cisplatin & $0.48 \pm 0.02$ & $1.56 \pm 0.26$ & $18.60 \pm 2.32$ & $10.31 \pm 2.54$ & $2.25 \pm 0.10$ & & \\
\hline
\end{tabular}

${ }^{\text {a }}$ MRC-5 = human lung fibroblasts, MCF-7 = breast cancer, HT-29 = colon cancer, HL-60 = human promyelocytic leukemia, Raji = human Burkitt's lymphoma, HeLa = cervix cancer, and A549 = lung cancer; ${ }^{b}$ The results are from three independent experiments, each performed in quadruplicate. SD were within $2 \%-5 \%$.

In a continuation, the antiproliferative activity of 74 and 75 was evaluated against five human tumor cell lines, MCF-7 (breast cancer), HT-29 (colon cancer), HL-60 (human promyelocytic leukemia), Raji (human Burkitt's lymphoma) and one human normal cell line MRC-5 (human lung fibroblasts) [33]. These complexes are less cytotoxic than cisplatin, with the exception of $\mathbf{7 4}$ in the case of the HT-29 cell line (Table 6). The latter complex showed the activity against all tested human tumor cell lines, being non-toxic in the MRC-5 cell line, while the cytotoxicity of L-Ala-L-His-Au(III) complex 75 was not observed against the tested cell line.

In addition, the cytotoxicity of all seven gold(III) complexes with X-L-His dipeptides 73-79 was assessed against two human cancer, cervix (HeLa) and lung (A549), cell lines and compared to the activity against the MRC-5 cell line (Table 6) [34]. As can be seen, these complexes did not manifest great anticancer potential; however, their cytotoxicity towards normal cell line was low $\left(\mathrm{IC}_{50}>100 \mu \mathrm{M}\right)$. Moreover, the complexes $\mathbf{7 6}$ and $\mathbf{7 9}$ showed significant antiangiogenic activity in vivo in a zebrafish embryos model (Figure 8). Although these two complexes achieved comparable antiangiogenic effect to the clinically used auranofin and sunitinib malate at 30-fold higher concentration, the zebrafish embryos following the treatment with $\mathrm{Au}(\mathrm{III})$ complexes had no cardiovascular side effects in comparison to those upon treatment with auranofin and sunitinib malate. The binding of the gold(III) complexes to the active sites of both human and bacterial (Escherichia coli) thioredoxin reductases (TrxRs) was confirmed by molecular docking study, suggesting that the mechanism of biological action of these complexes can be associated with their interaction with $\operatorname{TrxR}$ active site [34]. 


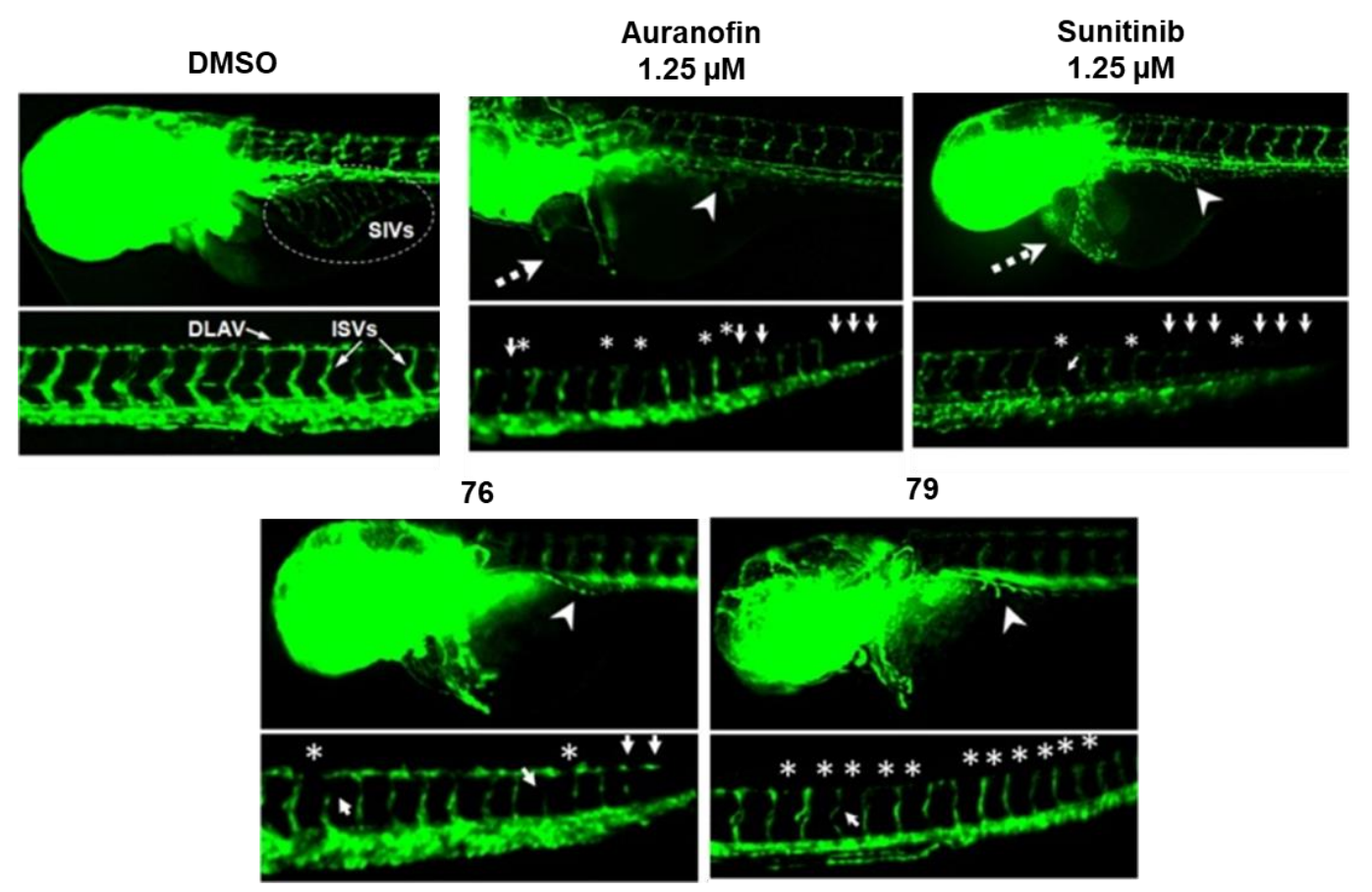

Figure 8. The effect of gold(III) complexes 76 and 79, sunitinib malate and auranofin on subintestinal vessels (SIVs), intersegmental vessels (ISVs) and dorsal longitudinal anastomotic vessels (DLAVs) development in zebrafish embryos. Reduced SIVs (arrowhead), disrupted DLAVs (asterisk), thinner or reduced ISVs (arrow), and pericardial edema (dashed arrow) are designated. The Figure was adapted from the Reference [34].

Additionally, the antimicrobial activity of the abovementioned gold(III) complexes with L-histidine-containing dipeptides 73-79 were evaluated against the Gram-positive (Staphylococcus aureus, Listeria monocytogenes, Enterococcus faecalis and Enterococcus faecium) and Gram-negative (Acinetobacter baumannii) bacteria and two strains of Candida (C. albicans and C. parapsilosis) [34]. In most cases, the minimal inhibitory concentration (MIC) values were between 200 and $400 \mu \mathrm{M}$, indicating their moderate to low activity. Nevertheless, the MIC values of 74 and 79 against Gram-positive E. faecium and Gram-negative A. baumannii were found to be 80 and $100 \mu \mathrm{M}$, respectively. Beside these results, a study related to the antimicrobial potential of a series of gold(III) complexes differing in the ligand structure, showed that two gold(III) complexes with L-histidine-containing dipeptides 74 and 75 exhibited relatively weak effects in comparison to the other studied complexes against the investigated bacterial strains [35].

\section{Conclusions}

The review article summarizes the results achieved in studies on the antiproliferative activity of gold(I) and gold(III) complexes containing amino acids and peptides as biocompatible ligands that can deliver a gold ion to its target. Except the biocompatibility of amino acids and peptides, the advantage of these ligands could be the fact that the tumor cells overexpress amino acids receptors, resulting in the selectivity of the obtained gold complexes toward the tumor cells in respect to the healthy ones. From the presented data, it could be seen that a large number of gold(I) and gold(III) complexes have been evaluated in vitro against different tumor cell lines, while the in vivo studies are rather scarce. In general, gold(I) complexes have shown higher cytotoxic activity than the gold(III) species, being, in some cases, superior in respect to the well-known anticancer agent, cisplatin. Except amino acids and peptides, the gold(I) complexes usually had phosphines and $N$-heterocyclic carbenes ancillary ligands, which also contributed to their biological properties. 
Gold(III) complexes with L-histidine-containing dipeptides, in which $N$-terminal amino acid is L-alanine and L-leucine, showed selectivity in terms of cancer vs. normal cell lines and achieved antiangiogenic effects comparable to the known inhibitors of angiogenesis-auranofin and sunitinib malate-without toxic-side effects, in contrast to those following auranofin and sunitinib malate treatment. These findings make them good candidates for the further development of antiangiogenic drugs.

From this review, it can be concluded that the use of amino acids and peptides as ligands for the synthesis of biologically active gold complexes has merit for the development of novel therapeutic agents for the treatment of cancer, which is a major burden of disease worldwide.

Funding: This research has been financially supported by the Ministry of Education, Science and Technological Development of the Republic of Serbia (Agreement No. 451-03-68/2020-14) and by the Serbian Academy of Sciences and Arts under strategic projects program-grant agreement No. 01-2019-F65 and project of this institution No. F128. The authors wish to thank Dr. Jasmina Nikodinovic-Runic (Institute of Molecular Genetics and Genetic Engineering, University of Belgrade) for her valuable comments on the manuscript.

Conflicts of Interest: The authors declare no conflicts of interest. The funders had no role in the collection, analyses or interpretation of the data, in writing of the manuscript and in the decision to publish the manuscript.

\section{References}

1. Huaizhi, Z.; Yuantao, N. China's ancient gold drugs. Gold Bull. 2001, 34, 24-29. [CrossRef]

2. Benedek, T.G. The history of gold therapy for tuberculosis. J. Hist. Med. Allied Sci. 2004, 59, 50-89. [CrossRef] [PubMed]

3. Fricker, S.P. Medical uses of gold compounds: Past, present and future. Gold Bull. 1996, 29, 53-60. [CrossRef]

4. Ott, I. On the medicinal chemistry of gold complexes as anticancer drugs. Coord. Chem. Rev. 2009, 253, 1670-1681. [CrossRef]

5. Nobili, S.; Mini, E.; Landini, I.; Gabbiani, C.; Casini, A.; Messori, L. Gold compounds as anticancer agents: Chemistry, cellular pharmacology, and preclinical studies. Med. Res. Rev. 2010, 30, 550-580. [CrossRef] [PubMed]

6. Berners-Price, S.J.; Filipovska, A. Gold compounds as therapeutic agents for human diseases. Metallomics 2011, 3, 863-873. [CrossRef]

7. Bertrand, B.; Casini, A. A golden future in medicinal inorganic chemistry: The promise of anticancer gold organometallic compounds. Dalton Trans. 2014, 43, 4209-4219. [CrossRef]

8. Nardon, C.; Boscutti, G.; Fregona, D. Beyond platinums: Gold complexes as anticancer agents. Anticancer Res. 2014, 34, 487-492.

9. Lima, J.C.; Rodríguez, L. Phosphine-Gold(I) compounds as anticancer agents: General description and mechanisms of action. Anti-Cancer Agents Med. Chem. 2011, 11, 921-928. [CrossRef]

10. Milacic, V.; Fregona, D.; Dou, Q.P. Gold complexes as prospective metal-based anticancer drugs. Histol. Histopathol. 2008, 23, 101-108.

11. Kostova, I. Gold coordination complexes as anticancer agents. Anti-Cancer Agents Med. Chem. 2006, 6, 19-32. [CrossRef] [PubMed]

12. Yeo, C.I.; Ooi, K.K.; Tiekink, E.R.T. Gold-based medicine: A paradigm shift in anti-cancer therapy? Molecules 2018, 23, 1410. [CrossRef] [PubMed]

13. Mora, M.; Gimeno, M.C.; Visbal, R. Recent advances in Gold-NHC complexes with biological properties. Chem. Soc. Rev. 2019, 48, 447-462. [CrossRef] [PubMed]

14. Glišić, B.Đ.; Djuran, M.I. Gold complexes as antimicrobial agents: An overview of different biological activities in relation to the oxidation state of the gold ion and the ligand structure. Dalton Trans. 2014, 43, 5950-5969. [CrossRef]

15. Navarro, M.; Gabbiani, C.; Messori, L.; Gambino, D. Metal-based drugs for malaria, trypanosomiasis and leishmaniasis: Recent achievements and perspectives. Drug Discov. Today 2010, 15, 1070-1078. [CrossRef] [PubMed]

16. Kastin, A.J. (Ed.) Handbook of Biologically Active Peptides; Elsevier: Amsterdam, The Netherland, 2006.

17. Peacock, A.F.A.; Bullen, G.A.; Gethings, L.A.; Williams, J.P.; Kriel, F.H.; Coates, J. Gold-phosphine binding to De Novo designed coiled coil peptides. J. Inorg. Biochem. 2012, 117, 298-305. [CrossRef] 
18. Astruc, D. Why is ferrocene so exceptional? Eur. J. Inorg. Chem. 2017, 2017, 6-29. [CrossRef]

19. Gimeno, M.C.; Goitia, H.; Laguna, A.; Luque, M.E.; Villacampa, M.D.; Sepúlveda, C.; Meireles, M. Conjugates of ferrocene with biological compounds. Coordination to gold complexes and antitumoral properties. J. Inorg. Biochem. 2011, 105, 1373-1382. [CrossRef]

20. Gutiérrez, A.; Bernal, J.; Villacampa, M.D.; Cativiela, C.; Laguna, A.; Gimeno, M.C. Synthesis of new gold(I) thiolates containing amino acid moieties with potential biological interest. Inorg. Chem. 2013, 52, 6473-6480. [CrossRef]

21. Gutiérrez, A.; Gracia-Fleta, L.; Marzo, I.; Cativiela, C.; Laguna, A.; Gimeno, M.C. Gold(I) thiolates containing amino acid moieties. Cytotoxicity and structure-activity relationship studies. Dalton Trans. 2014, 43, 17054-17066. [CrossRef]

22. Ghosh, S. Cisplatin: The first metal based anticancer drug. Bioorg. Chem. 2019, 88, 102925. [CrossRef] [PubMed]

23. Gutiérrez, A.; Marzo, I.; Cativiela, C.; Laguna, A.; Gimeno, M.C. Highly cytotoxic bioconjugated gold(I) complexes with cysteine-containing dipeptides. Chem. Eur. J. 2015, 21, 11088-11095. [CrossRef] [PubMed]

24. Gutiérrez, A.; Cativiela, C.; Laguna, A.; Gimeno, M.C. Bioactive gold(I) complexes with 4-mercaptoproline derivatives. Dalton Trans. 2016, 45, 13483-13490. [CrossRef] [PubMed]

25. Gutiérrez, A.; Gimeno, M.C.; Marzo, I.; Metzler-Nolte, N. Synthesis, characterization, and cytotoxic activity of $\mathrm{Au}^{\mathrm{I}} \mathrm{N}, \mathrm{S}$-heterocyclic carbenes derived from peptides containing L-thiazolylalanine. Eur. J. Inorg. Chem. 2014, 2014, 2512-2519. [CrossRef]

26. Lemke, J.; Pinto, A.; Niehoff, P.; Vasylyeva, V.; Metzler-Nolte, N. Synthesis, structural characterisation and anti-proliferative activity of NHC gold amino acid and peptide conjugates. Dalton Trans. 2009, 7063-7070. [CrossRef]

27. Kouodom, M.N.; Ronconi, L.; Celegato, M.; Nardon, C.; Marchiò, L.; Dou, Q.P.; Aldinucci, D.; Formaggio, F.; Fregona, D. Toward the selective delivery of chemotherapeutics into tumor cells by targeting peptide transporters: Tailored gold-based anticancer peptidomimetics. J. Med. Chem. 2012, 55, 2212-2226. [CrossRef]

28. Brown, K.L.; Hancock, R.E.W. Cationic host defense (antimicrobial) peptides. Curr. Opin. Immunol. 2006, 18, 24-30. [CrossRef]

29. Johnstone, S.A.; Gelmon, K.; Mayer, L.D.; Hancock, R.E.; Bally, M.B. In vitro characterization of the anticancer activity of membrane-active cationic peptides. I. Peptide-mediated cytotoxicity and peptide-enhanced cytotoxic activity of doxorubicin against wild-type and p-glycoprotein over-expressing tumor cell lines. Anti-Cancer Drug Des. 2000, 15, 151-160.

30. Toniolo, C.; Brückner, H. Peptaibiotics; Wiley-VCD: Weinheim, Germany; Wiley-VHCA: Zürich, Switzerland, 2009.

31. Kouodom, M.N.; Boscutti, G.; Celegato, M.; Crisma, M.; Sitran, S.; Aldinucci, D.; Formaggio, F.; Ronconi, L.; Fregona, D. Rational design of gold(III)-dithiocarbamato peptidomimetics for the targeted anticancer chemotherapy. J. Inorg. Biochem. 2012, 117, 248-260. [CrossRef]

32. Carotti, S.; Marcon, G.; Marussich, M.; Mazzei, T.; Messori, L.; Mini, E.; Orioli, P. Cytotoxicity and DNA binding properties of a chloro glycylhistidinate gold(III) complex (GHAu). Chem. Biol. Interact. 2000, 125, 29-38. [CrossRef]

33. Glišić, B.Đ.; Stanić, Z.D.; Rajković, S.; Kojić, V.; Bogdanović, G.; Djuran, M.I. Solution study under physiological conditions and cytotoxic activity of the gold(III) complexes with L-histidine-containing peptides. J. Serb. Chem. Soc. 2013, 78, 1911-1924. [CrossRef]

34. Warżajtis, B.; Glišić, B.Đ.; Savić, N.D.; Pavic, A.; Vojnovic, S.; Veselinović, A.; Nikodinovic-Runic, J.; Rychlewska, U.; Djuran, M.I. Mononuclear gold(III) complexes with L-histidine-containing dipeptides: Tuning the structural and biological properties by variation of the $N$-terminal amino acid and counter anion. Dalton Trans. 2017, 46, 2594-2608. [CrossRef] [PubMed]

35. Radulović, N.S.; Stojanović, N.M.; Glišić, B.Đ.; Randjelović, P.J.; Stojanović-Radić, Z.Z.; Mitić, K.V.; Nikolić, M.G.; Djuran, M.I. Water-soluble gold(III) complexes with N-donor ligands as potential immunomodulatory and antibiofilm agents. Polyhedron 2018, 141, 164-180. [CrossRef]

(C) 2020 by the authors. Licensee MDPI, Basel, Switzerland. This article is an open access article distributed under the terms and conditions of the Creative Commons Attribution (CC BY) license (http://creativecommons.org/licenses/by/4.0/). 